\title{
Zircon U/Pb dating and Hf-O isotopes of the Zhouan ultramafic intrusion in the northern margin of the Yangtze Block, SW China: Constraints on the nature of mantle source and timing of the supercontinent Rodinia breakup
}

\author{
WANG MengXi ${ }^{1,2}$, WANG ChristinaYan ${ }^{1 *} \&$ ZHAO JunHong ${ }^{3}$ \\ ${ }^{1}$ Key Laboratory of Mineralogy and Metallogeny, Guangzhou Institute of Geochemistry, Chinese Academy of Sciences, \\ Guangzhou 510640, China; \\ ${ }^{2}$ Graduate University of Chinese Academy of Sciences, Beijing 100049, China; \\ ${ }^{3}$ Department of Earth Sciences, China University of Geosciences, Wuhan 430074, China
}

Received May 14, 2012; accepted July 30, 2012; published online August 27, 2012

The Zhouan ultramafic intrusion in the northern margin of the Yangtze Block is mainly composed of lherzolite. Zircon grains selected from lherzolite are irregular in shape with distinct oscillatory and sector zoning and have Th/U ratios ranging from 0.8 to 10.6 , indicating a magmatic origin. The weighted average ${ }^{206} \mathrm{~Pb} /{ }^{238} \mathrm{U}$ age is $637 \pm 4 \mathrm{Ma}(2 \sigma, n=15)$, which can be considered as the crystallization age of the Zhouan intrusion. Zircon grains have $\delta^{18} \mathrm{O}$ values ranging from $5.2 \%$ to $7.0 \%$, with an averaged value of $5.8 \pm 0.4 \%$ o $(1 \sigma, n=33)$, similar to the mantle $\delta^{18} \mathrm{O}$ value of zircon. Their ${ }^{176} \mathrm{Hf} /{ }^{177} \mathrm{Hf}_{(t)}$ ratios range from 0.282410 to 0.282594 with $\varepsilon_{\mathrm{Hf}}(t)$ values ranging from 1.3 to 7.6, lower than the corresponding value of the depleted mantle ( $\left.\sim 15\right)$, indicating an enriched mantle source. The enriched mantle source may have generated from a metasomatized lithospheric mantle with subducted slab. A number of $\sim 635$ Ma mafic-ultramafic intrusions in the Suizao basin are associated with coeval bimodal volcanics of the Yaolinghe Formation, indicating a continental rift setting. The $\sim 635$ Ma magmatic event in this region may represent the product of the last breakup of the Rodinia supercontinent in the northern margin of the Yangtze Block at Neoproterozoic.

zircon Hf-O isotopes, Zhouan ultramafic intrusion, northern margin of the Yangtze Block, Neoproterozoic

Citation: Wang M X, Wang C Y, Zhao J H. Zircon U/Pb dating and Hf-O isotopes of the Zhouan ultramafic intrusion in the northern margin of the Yangtze Block, SW China: Constraints on the nature of mantle source and timing of the supercontinent Rodinia breakup. Chin Sci Bull, 2013, 58: 777-787, doi: $10.1007 / \mathrm{s} 11434-012-5435-1$

Neoproterozoic (850-630 Ma) magmatic rocks are widely distributed in the northern, western and southeastern margins of the Yangtze Block, which is considered to be part of the Rodinia supercontinent [1-3]. 850-630 Ma magmatic rocks are mainly composed of granitoid plutons and associated mafic-ultramafic intrusions and coeval volcanic rocks [4-16]. These intrusive bodies have arc-like characters in geochemistry, indicating that the margins of the Yangtze Block may have undergone subduction of oceanic slab in early stage (1160-930 Ma) and large-scaled extension in late stage $[6,7,17-21]$. However, it remains debated in the

*Corresponding author (email: wang_yan@gig.ac.cn) timing and mechanism of such a transformation. Three hypotheses have been proposed for the mechanism of the transformation, including mantle plume, lithospheric extension-rifting and subduction in a continental margin. Some workers suggested that $<850$ Ma magmatic rocks in the margins of the Yangtze Block may have formed by partial melting of the lithospheric mantle and lower crust triggered by a mantle plume $[6,7,22]$. Others argued that $830-820 \mathrm{Ma}$ magmatic events were related to post-collisional extension and 780-740 Ma magmatic events were related to continental rifting [23]. Also some workers proposed that most of Neoproterozoic magmatic events along the margins of the Yangtze Block were related to subduction in an active 
continental margin [4,24].

Previous studies indicate that the mechanism and timing of the transformation from subduction to extension at Neoproterozoic in the western and northern margins are different from the southeastern margin of the Yangtze Block. Amalgamation of the Yangtze and Cathaysia Blocks at Neoproterozoic along the southeastern margin of the Yangtze Block formed the South China and led to the formation of the Jiangnan folded belt and deformation and metamorphism of the Sibao Formation [25]. Subsequent intracontinental breakup of the South China resulted in intensive magmatism and the formation of the Nanhua basin composed mainly of the Banxi Formation [26]. New zircon $\mathrm{U}-\mathrm{Pb}$ age data indicated that the Grenvillian Jiangnan folded belt formed at $~ 830 \mathrm{Ma}$ [27] and subsequent breakup may have lasted from $814 \pm 12$ Ma to $725 \pm 10 \mathrm{Ma}[26,28]$.

The mechanism and timing of the transformation from subduction to extension at Neoproterozoic in the western and northern margins of the Yangtze Block are debated. They are supposed to be the same as the southeastern margin in terms of timing and mechanism according to the models of mantle plume and lithospheric extension-rifting $[6,7,22,23]$. However, it is argued that the western and northern margins of the Yangtze Block had been active continental margins until 735 Ma [4,5,9-13]. But it remains unknown when the final breakup occurred in the western and northern margins of the Yangtze Block.

A number of 640-630 Ma mafic-ultramafic intrusions in the northern margin of the Yangtze Block are distributed in the Suizao basin in the south Qinling area [14-16]. Among them, the Zhouan ultramafic intrusion hosts Ni-Cu-(PGE) sulfide mineralization [29]. In general, mafic-ultramafic intrusions with sulfide mineralization are related to intensive magmatic events in a rift setting [30]. In this study, we present zircon $\mathrm{U}-\mathrm{Pb}$ age data and $\mathrm{Hf}-\mathrm{O}$ isotopes for the Zhouan intrusion. The data set enables us to discuss the formation age and the nature of mantle source for the Zhouan intrusion. Together with available $\mathrm{Sr}-\mathrm{Nd}$ isotopic data of the Neoproterozoic mafic-ultramafic intrusions and basaltic lavas in the northern margin of the Yangtze Block, we discuss the evolution of the mantle sources of these $\mathrm{Ne}$ oproterozoic mafic-ultramafic intrusions and the final breakup time of the Rodinian supercontinent in the northern margin of the Yangtze Block.

\section{Geological background}

The Yangtze Block amalgamated with the Cathaysia Block by the Jiangnan folded belt in its southeastern margin during Meso- to Neoproterozoic [31]. It is separated from the North China Block by the Qinling-Dabie-Sulu orogenic belt to the north and bounded by the Tibetan Plateau to the west (Figure 1).

The Yangtze Block consists of a Precambrian basement overlain by a sedimentary sequence of the late Mesoproterozoic to upper Jurassic. The basement consists of Archean amphibolite (i.e. the 3.2 Ga Kongling Terrane), Mesoproterozoic meta-sedimentary rocks [32-36], Neoproterozoic strata and numerous magmatic plutons [4,5,37,38]. The sedimentary sequence $(>9 \mathrm{~km})$ is mainly composed of clastic, carbonate, meta-volcanic rocks and glacial deposits [39].

Neoproterozoic magmatism in the Yangtze Block yielded voluminous 820-630 Ma mafic-ultramafic intrusions which are distributed in the Guibei area in the southeastern margin $[22,40]$, in the Panxi area in the western margin $[9,37,41]$, and in the Hannan and Suizao areas in the northern margin of the Yangtze Block [13-16].

In the Hannan area, $819 \pm 10$ Ma Wangjiangshan layered gabbroic intrusion with $\mathrm{Cu}-\mathrm{Ni}$ sulfide mineralization [4] and $782 \pm 10$ Ma Bijigou gabbroic-dioritic intrusion with $\mathrm{V}-\mathrm{Ti}$ magnetite mineralization [4] intruded the Paleoproterozoic Houhe Formation, Meso-Neoproterozoic Huodiya Formation and Neoproterozoic Xixiang Formation. The Houhe Formation (2081 \pm 9 Ma [42]) experienced high amphibolite facies metamorphism and migmatization and mainly consists of tonalitic gneiss, with small amounts of amphibolite and marble $[43,44]$. The Houhe Formation is unconformably overlain by the Huodiya Formation which is composed of meta-sedimentary rocks in the lower part and metavolcanic rocks in the upper part [11]. The Xixiang Formation (950 $\pm 4 \mathrm{Ma}-895 \pm 3 \mathrm{Ma}$ [44]) mainly consists of a sequence of volcanic and sedimentary rocks, possibly of back-arc basin origin [10]. Moreover, numerously coeval granitic plutons occur in the Hannan area, such as the adakite-like $735 \pm 8$ Ma Wudumen and $730 \pm 6$ Ma Erliba plutons [11] and the 762 $\pm 4 \mathrm{Ma}$ arc-like Tianpinghe granite [12].

A number of 640-630 Ma mafic-ultramafic intrusions occur in the Suizao basin, including the $641 \pm 5$ Ma Zhouan intrusion [16], 638 $\pm 10 \mathrm{Ma}$ Changling intrusion, 636 $\pm 11 \mathrm{Ma}$ Shoushan intrusion [14], 632 \pm 6 Ma Duchongshan intrusion [15] and 631 \pm 11 Ma Bashan intrusion [14]. These intrusions intruded the Meso-Neoproterozoic Zhujiashan Formation and the Neoproterozoic Suixian Formation. The Daqueshan unit of the Zhujiashan Formation is composed of interlayered marble and schist [29]. The Suixian Formation consists of bimodal meta-volcanic rocks with minor interlayers of meta-sedimentary rock in the lower part, meta-sedimentary rocks with interlayers of meta-rhyolitic pyroclastic rock and metamorphosed intermedium-basic lavas in the middle part, and meta-sedimentary rocks in the upper part with metatrachyandensite or alkaline rhyolite in local places [15]. Coeval Yaolinghe Formation in the Wudang Terrane is a suite of bimodal assemblage composed mainly of metabasaltic volcanic lava, tephra or tuff and small amounts of meta-felsic lava and argillaceous rocks, which is interpreted as the product in a continental rift setting [45-47]. Several different ages were reported for the Yaolinghe Formation, the whole-rock $\mathrm{Sm}-\mathrm{Nd}$ isochron age is reported to be 


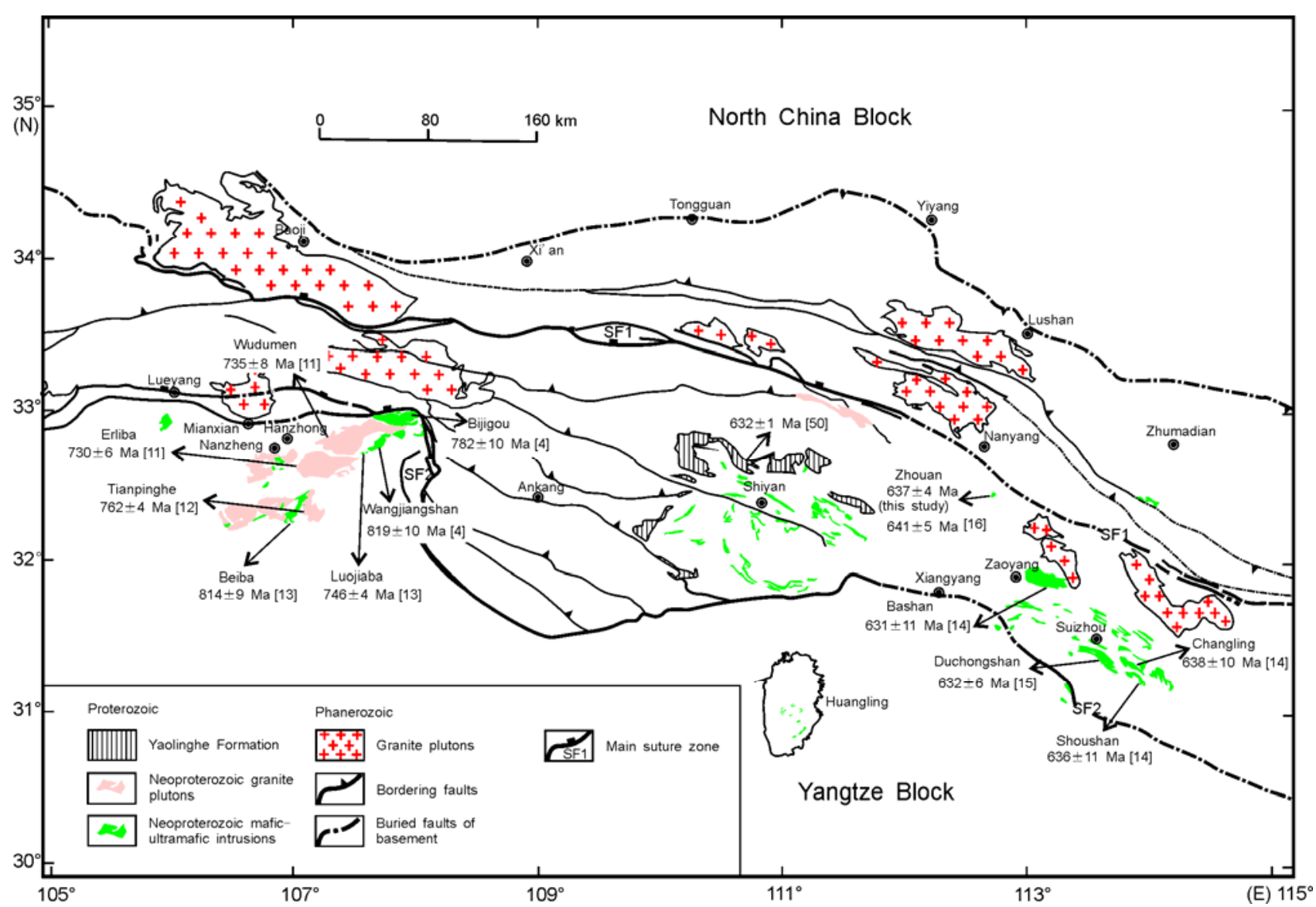

Figure 1 Simplified geologic map showing the distribution of Neoproterozoic mafic-ultramafic intrusions, volcanic rocks and granitic plutons in the northern margin of the Yangtze Block, SW China.

$780-1000 \mathrm{Ma}[48,49]$, whereas an zircon $\mathrm{U}-\mathrm{Pb}$ age is $685 \pm 5$ Ma for the metamorphic rhyolitic lavas and crystal-lithic tuffaceous pyroclastic rocks [46] and is $632 \pm 1$ Ma for the metamorphic spilite-keratophyre-tuff [50]. The latter is identical with the ages of the mafic-ultramafic intrusions in the Suizao basin.

\section{Analytical method}

The Zhouan intrusion mainly consists of lherzolite. Lherzolite is composed of olivine $(65 \%-70 \%)$, clinopyroxene $(10 \%-15 \%)$ and orthopyroxene $(10 \%-15 \%)$. Zircon grains were separated from $\sim 20 \mathrm{~kg}$ lherzolite using conventional heavy liquid and magnetic technique in uncontaminated condition and handpicked with binocular microscope. Zircon separates were mounted on adhesive tape, enclosed in epoxy resin with zircon standard (Qinghu, Plésovice and 91500), polished down to expose the centers of zircon grains and finally coated with gold. Zircon grains were photographed in transmitted, reflected light and cathodoluminescence (CL) to select the appropriate analytical location. CL images were taken using a scanning electron microscope at the State Key Laboratory of Continental Dy- namics, Northwest University, Xi'an. Zircon in-situ oxygen isotopes were analyzed firstly, and then $\mathrm{U} / \mathrm{Pb}$ dating and $\mathrm{Hf}$ isotope were analyzed successively in the same location.

\subsection{Zircon oxygen isotope}

Zircon in-situ oxygen isotopes were measured using the Cameca IMS 1280 large-radius SIMS at Ion Microprobe Laboratory in the Institute of Geology and Geophysics (IGG), Chinese Academy of Sciences (CAS) in Beijing. Analytical procedures are the same as those described by $\mathrm{Li}$ et al. [51-54]. The $\mathrm{Cs}^{+}$primary ion beam with an intensity of $\sim 2 \mathrm{nA}$ was accelerated at $10 \mathrm{kV}$ and bombarded the surface of zircon grains. The spot is about $20 \mu \mathrm{m}$ in diameter, including $10 \mu \mathrm{m}$ beam diameter and $10 \mu \mathrm{m}$ raster. The normal-incidence electron flood gun was used to compensate for sample charging during analysis with homogeneous electron density over $100 \mu \mathrm{m}$ oval area. Negative secondary ions were extracted with a $-10 \mathrm{kV}$ potential. The field aperture was set to $5000 \mu \mathrm{m}$ and energy window was $30 \mathrm{eV}$, together with a mass resolution of $\sim 2500$. Oxygen isotopes were measured using multi-collector mode on two off-axis Farady cups. One analysis takes $\sim 5 \mathrm{~min}$ including presputtering ( $2 \mathrm{~min})$, automatic beam centering ( 60 s) and 
integration of oxygen isotopes ( 20 cycles $\times 4 \mathrm{~s})$. Uncertainties on individual analyses are usually better than $0.2 \%$ $0.3 \% \circ(1 \sigma)$ and the external accuracy of zircon standard is $0.5 \%$ (2SD). The instrumental mass fractionation factor (IMF) is corrected using zircon Penglai standard [55]. Measured ${ }^{18} \mathrm{O} /{ }^{16} \mathrm{O}$ ratios were normalized by using Vienna Standard Mean Ocean Water compositions (VSMOW, $\left.{ }^{18} \mathrm{O} /{ }^{16} \mathrm{O}=0.0020052\right)$, then corrected for the IMF as follows: $\left(\delta^{18} \mathrm{O}\right)_{\mathrm{M}}=\left(\left({ }^{18} \mathrm{O} /{ }^{16} \mathrm{O}\right)_{\mathrm{M}} / 0.0020052-1\right) \times 1000 \quad(\%), \quad \mathrm{IMF}=$ $\left(\delta^{18} \mathrm{O}\right)_{\mathrm{M}(\text { standard })}\left(\delta^{18} \mathrm{O}\right)_{\mathrm{VSMOW}}, \delta^{18} \mathrm{O}_{\text {sample }}=\left(\delta^{18} \mathrm{O}\right)_{\mathrm{M}}+\mathrm{IMF}$ [54].

\subsection{Zircon U-Pb age dating}

Zircon U-Pb dating were measured using the same Cameca IMS 1280 SIMS at the Ion Microprobe Laboratory in IGG CAS. Analytical procedures are the same as those described by $\mathrm{Li}$ et al. [51-54]. The $\mathrm{O}_{2}^{-}$primary ion beam was accelerated at $-13 \mathrm{kV}$, with an intensity of $\sim 10 \mathrm{nA}$. The ellipsoidal spot is about $20 \mu \mathrm{m} \times 30 \mu \mathrm{m}$ in size [54]. A $60 \mathrm{eV}$ energy window was used in the secondary ion beam optical, together with a mass resolution of $\sim 5400$ to separate $\mathrm{Pb}^{+}$ peaks from isobaric interferences. In the secondary ion optics, rectangular lenses were used to increase the transmission at high mass resolution. $\mathrm{Pb}^{+}$sensitivity for zircon enhanced by the oxygen flooding which was used to increase the $\mathrm{O}_{2}$ pressure to $\sim 5 \times 10^{-6}$ Torr in the sample chamber. Secondary ion beam intensities were measured by peak jumping with a single electron multiplier. Each measurement includes seven cycles, and the total analytical time is about $10 \mathrm{~min}$. Zircon U-Th-Pb isotopic ratios were corrected using zircon Plésovice standard [56]. Single point errors were gained via propagation of long-term monitoring standard deviation $1.5 \%(1 \sigma)$ [57] for zircon standard and individual internal accuracy. Calibration of $\mathrm{Pb} / \mathrm{U}$ ratios is relative to the zircon 91500 (1065 Ma) standard. Th and U concentrations were determined relative to zircon 91500 standard ( $\mathrm{Th}=29 \mathrm{ppm} ; \mathrm{U}=81 \mathrm{ppm})$ [58]. Correction of common $\mathrm{Pb}$ was made by using non-radiogenic ${ }^{204} \mathrm{~Pb}$. Although the low abundance of ${ }^{204} \mathrm{~Pb}$ makes the correction relatively imprecise, it can provide the direct measure of common $\mathrm{Pb}$ [51]. Uncertainties on individual analyses are reported at $1 \sigma$ level.

\subsection{Zircon Lu-Hf isotopes}

Zircon in situ Lu-Hf isotopes were measured on a Neptune multi-collector ICP-MS equipped with a Geolas-193 laser-ablation system (LA-MC-ICP-MS) at MC-ICPMS Laboratory in IGG CAS. Analytical procedures are the same as those described by $\mathrm{Wu}$ et al. [59]. Typical ablation time for each analysis is $26 \mathrm{~s}$, with a $10 \mathrm{~Hz}$ repetition rate, 100 $\mathrm{mJ} /$ pulse laser power and ablation pit of $\sim 60 \mu \mathrm{m}$ in diameter. Isobaric interference of ${ }^{176} \mathrm{Lu}$ and ${ }^{176} \mathrm{Yb}$ on ${ }^{176} \mathrm{Hf}$ signal were subtracted by monitoring the intensity of ${ }^{175} \mathrm{Lu}$ and ${ }^{172} \mathrm{Yb}$ signals, using ${ }^{176} \mathrm{Lu} /{ }^{175} \mathrm{Lu}(0.02655)[60]$ and ${ }^{176} \mathrm{Yb} /{ }^{172} \mathrm{Yb}$ (0.5886) [61]. External monitor of instrument drift was done by using cross analysis of zircon 91500 standard and samples. The ${ }^{176} \mathrm{Hf} /{ }^{177} \mathrm{Hf}$ and ${ }^{176} \mathrm{Lu} /{ }^{177} \mathrm{Hf}$ ratios of zircon 91500 standard were $0.282294 \pm 15(2 \sigma, n=20)$ and 0.00031 during the analyses, respectively, approximately similar to the results measured by solution method. $\varepsilon_{\mathrm{Hf}}$ values were calculated using $1.867 \times 10^{-11} \mathrm{a}^{-1}[62]$ as ${ }^{176} \mathrm{Lu}$ decay constant, and present-day ${ }^{176} \mathrm{Hf} /{ }^{177} \mathrm{Hf}=0.282772,{ }^{176} \mathrm{Lu} /{ }^{177} \mathrm{Hf}=0.0332$ [63] for chondrite. The depleted mantle array was calculated by assuming its present-day ${ }^{176} \mathrm{Hf} /{ }^{177} \mathrm{Hf}=0.28325$ and ${ }^{176} \mathrm{Lu} /$ ${ }^{177} \mathrm{Hf}=0.0384$ [64].

\section{Analytical results}

\subsection{Zircon morphology}

Zircons are colorless and transparent, and irregular in shape. They range in size from 50 to $120 \mu \mathrm{m}$ in length with length/width ratios of about $1: 1$ to $3: 1$. CL images of the zircons show that most zircon grains have distinct oscillatory and sector zoning without core-rim structure, typical of the origin from mafic magmas (Figure 2).

\subsection{Zircon U-Pb ages}

A total of 33 spots on 33 zircon grains were analyzed for $\mathrm{U}-\mathrm{Pb}$ ages. Zircons have $\mathrm{U}$ concentrations ranging from 40 to $1024 \mathrm{ppm}$ and Th from 127 to $2342 \mathrm{ppm}$. Zircons have $\mathrm{Th} / \mathrm{U}$ ratios varying from 0.8 to 10.6 (Table 1 ), consistent with zircons $(\mathrm{Th} / \mathrm{U}>0.5$ [65]) crystallized from mafic magmas. On the plot of ${ }^{206} \mathrm{~Pb} /{ }^{238} \mathrm{U}$ versus ${ }^{207} \mathrm{~Pb} /{ }^{235} \mathrm{U}$, lead loss line intersects with concordia at zero, indicating that a present-day $\mathrm{Pb}$ loss due to exposure to the open air and weathering of samples. However, ${ }^{207} \mathrm{~Pb} /{ }^{206} \mathrm{~Pb}$ ages of all the grains are concordant (Figure 3(a)), with a weighted mean age of $635 \pm 8 \mathrm{Ma}(2 \sigma)$. Fifteen analyses, with greater than $95 \%$ confidence, yield a weighted mean ${ }^{206} \mathrm{~Pb} /{ }^{238} \mathrm{U}$ age of $637 \pm 4 \mathrm{Ma}(2 \sigma)$ (Figure 3(b)), which is considered to be the crystallization age of the intrusion.

\subsection{Zircon oxygen isotope}

$\delta^{18} \mathrm{O}$ values of 33 zircon spots range from $5.2 \%$ o to $7.0 \%$ o with an averaged value of $5.8 \pm 0.4 \%$ o $(1 \sigma, n=33)$ (Table 1). The $\delta^{18} \mathrm{O}$ values show a Gaussian distribution (Figure 4(a)), indicating that the zircons have homogeneous $\mathrm{O}$ isotopic compositions. Twenty-six zircon grains have $\delta^{18} \mathrm{O}$ values similar to the mantle value $(5.3 \pm 0.3 \%$ o $)$ [66], whereas the other seven grains have $\delta^{18} \mathrm{O}$ values slightly higher than the mantle value (Figure 4(b)). Zircons with $>95 \%$ confidence for $\mathrm{U}-\mathrm{Pb}$ age dating have $\delta^{18} \mathrm{O}$ values ranging from $5.2 \%$ to $7.0 \%$ and those with $<95 \%$ confidence from $5.3 \%$ to $6.4 \%$, generally identical within the uncertainties (Table 1, Figure 4(b)). 

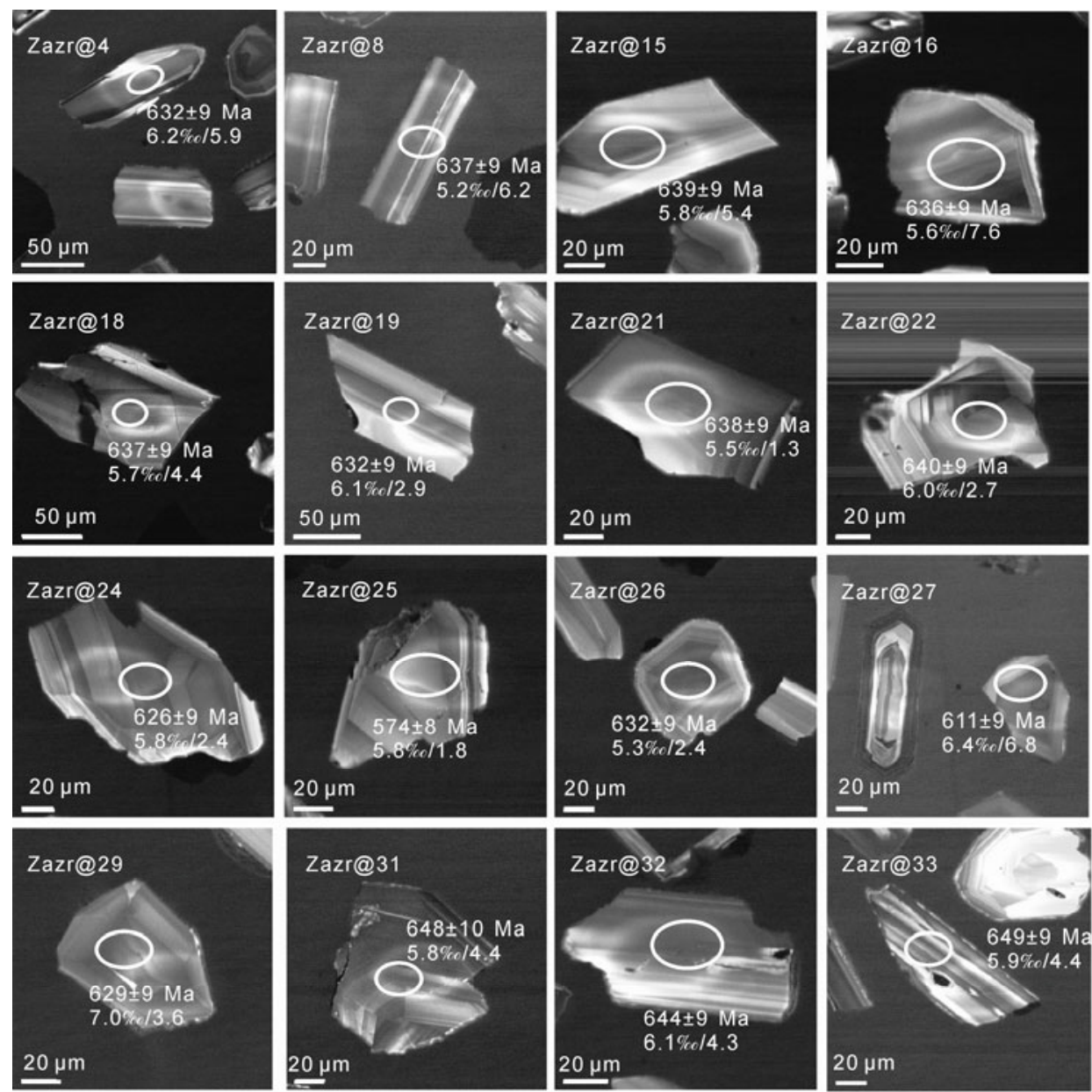

Figure 2 Cathodoluminescence (CL) images of zircons selected from lherzolite of the Zhouan intrusion. Analytical spots for U-Pb dating and Hf-O isotopes are illustrated with ellipses on the grains and the numbers near ellipses are $\mathrm{U}-\mathrm{Pb}$ ages, $\delta^{18} \mathrm{O}$ and $\varepsilon_{\mathrm{Hf}}(t)$ values.

\subsection{Zircon Lu-Hf isotopes}

Zircons with $>95 \%$ confidence for U-Pb age dating have present-day ${ }^{176} \mathrm{Lu} /{ }^{177} \mathrm{Hf}$ ratios ranging from 0.0002 to 0.0016 and ${ }^{176} \mathrm{Hf} /{ }^{177} \mathrm{Hf}$ ratios from 0.282421 to 0.282608 . They have initial ${ }^{176} \mathrm{Hf} /{ }^{177} \mathrm{Hf}$ ratios varying from 0.282410 to 0.282589 and $\varepsilon_{\mathrm{Hf}}(t)$ values between 1.3 and 7.6 when calculated by $t=637 \mathrm{Ma}$ (Table 2, Figure 5(a)). Zircons with $<95 \%$ confidence have present-day ${ }^{176} \mathrm{Lu} /{ }^{177} \mathrm{Hf}$ ratios ranging from 0.0003 to 0.0023 and ${ }^{176} \mathrm{Hf} /{ }^{177} \mathrm{Hf}$ ratios from 0.282453 to 0.282620 . They have initial ${ }^{176} \mathrm{Hf} /{ }^{177} \mathrm{Hf}$ ratios ranging from 0.282450 to 0.282594 and $\varepsilon_{\mathrm{Hf}}(t)(t=637 \mathrm{Ma})$ values between 2.1 and 6.9 (Table 2, Figure 5(a)).

\section{Discussion}

\subsection{Enriched mantle source}

The greater affinity for $\mathrm{Hf}$ than $\mathrm{Lu}$ in zircon means that $\mathrm{Lu} / \mathrm{Hf}$ ratio in zircon is invariably very low $(\sim 0.002)$ and the ${ }^{176} \mathrm{Lu} /{ }^{177} \mathrm{Hf}$ ratios of zircon are usually $<0.0005$. Initial ${ }^{176} \mathrm{Hf} /{ }^{177} \mathrm{Hf}$ ratios of zircons crystallized from mafic magmas are often very similar to the present-day value because timeintegrated changes to the ${ }^{176} \mathrm{Hf} /{ }^{177} \mathrm{Hf}$ ratio as a result of in situ decay of ${ }^{176} \mathrm{Lu}$ proceed are at negligible rates [67]. When the primitive mantle differentiated to form the depleted mantle and continental crust, the depleted mantle acquired a Lu/Hf ratio several times greater than the continental crust [68]. Therefore, the ${ }^{176} \mathrm{Hf} /{ }^{177} \mathrm{Hf}$ ratio of the depleted mantle increased faster than the continental crust so that $\varepsilon \mathrm{Hf}$ values of the depleted mantle became more and more positive with time, whereas $\varepsilon_{\mathrm{Hf}}$ values of the continental crust more and more negative with time [68]. Zircons that crystallized from a mixing magma of two end-members, the depleted mantle and a continental crust, are supposed to have $\varepsilon_{\mathrm{Hf}}$ values between these two end members. On the other hand, zircons from mafic magmas that have no assimilation of crustal component and have $\varepsilon_{\mathrm{Hf}}$ values positive but lower than the coeval depleted mantle, may indicate that the mafic magmas were derived from an enriched mantle source [68]. Zircons from the Zhouan intrusion have $\varepsilon_{\mathrm{Hf}}(t)$ values ranging from 1.3 to 7.6 , distinctly lower than coeval depleted mantle (15)(Figure 5(a)). The rocks from the Zhouan intrusion have nearly constant $\mathrm{Zr} / \mathrm{Nb}(13-17)$ and $\mathrm{La} / \mathrm{Nb}$ 
Table 1 Zircon U-Pb age and oxygen isotopic compositions for the Zhouan intrusion

\begin{tabular}{|c|c|c|c|c|c|c|c|c|c|c|c|c|c|c|c|c|c|}
\hline \multirow{2}{*}{$\begin{array}{c}\text { Spot } \\
\text { number }\end{array}$} & \multicolumn{4}{|c|}{ Concentrations } & \multicolumn{6}{|c|}{ Isotopic ratios } & \multicolumn{6}{|c|}{ Ages (Ma) } & \multirow{2}{*}{$\begin{array}{l}\begin{array}{c}\text { Oxygen } \\
\text { isotope }\end{array} \\
\delta^{18} \mathrm{O}(\%)\end{array}$} \\
\hline & $\begin{array}{c}\mathrm{U} \\
(\mathrm{ppm})\end{array}$ & $\begin{array}{c}\text { Th } \\
(\mathrm{ppm})\end{array}$ & $\begin{array}{c}\mathrm{Pb} \\
(\mathrm{ppm})\end{array}$ & $\mathrm{Th} / \mathrm{U}$ & ${ }^{207} \mathrm{~Pb} /{ }^{206} \mathrm{~Pb}$ & $\begin{array}{c} \pm(1 \sigma) \\
(\%)\end{array}$ & ${ }^{207} \mathrm{~Pb} /{ }^{235} \mathrm{U}$ & $\begin{array}{c} \pm(1 \sigma) \\
(\%)\end{array}$ & ${ }^{206} \mathrm{~Pb} /{ }^{238} \mathrm{U}$ & $\begin{array}{c} \pm(1 \sigma) \\
(\%)\end{array}$ & ${ }^{207} \mathrm{~Pb} /{ }^{206} \mathrm{Pt}$ & $\mathrm{b} \pm(1 \sigma)$ & ${ }^{207} \mathrm{~Pb} /{ }^{235} \mathrm{U}$ & $\mathrm{U} \pm(1 \sigma)^{2}$ & ${ }^{206} \mathrm{~Pb} /{ }^{238} \mathrm{C}$ & ${ }^{8} \mathrm{U} \pm(1 \sigma)$ & \\
\hline Zazr@1 & 212 & 584 & 42 & 2.76 & 0.0604 & 1.25 & 0.8842 & 1.97 & 0.1061 & 1.52 & 619 & 27 & 643 & 9 & 650 & 9 & 5.8 \\
\hline Zazr@2 & 269 & 1561 & 79 & 5.81 & 0.0616 & 1.07 & 0.8735 & 1.87 & 0.1029 & 1.53 & 659 & 23 & 638 & 9 & 631 & 9 & 5.5 \\
\hline Zazr@3 & 103 & 190 & 16 & 1.85 & 0.0618 & 2.47 & 0.8335 & 2.89 & 0.0978 & 1.50 & 667 & 52 & 616 & 13 & 602 & 9 & 5.4 \\
\hline Zazr@4 & 512 & 878 & 83 & 1.71 & 0.0610 & 1.23 & 0.8651 & 1.94 & 0.1029 & 1.50 & 638 & 26 & 633 & 9 & 632 & 9 & 6.2 \\
\hline Zazr@5 & 154 & 448 & 30 & 2.90 & 0.0607 & 1.54 & 0.8439 & 2.15 & 0.1008 & 1.51 & 630 & 33 & 621 & 10 & 619 & 9 & 5.5 \\
\hline Zazr@6 & 194 & 339 & 29 & 1.75 & 0.0612 & 1.84 & 0.8070 & 2.38 & 0.0956 & 1.50 & 647 & 39 & 601 & 11 & 589 & 8 & 5.6 \\
\hline Zazr@7 & 213 & 1469 & 70 & 6.88 & 0.0591 & 1.41 & 0.8315 & 2.06 & 0.1021 & 1.50 & 570 & 31 & 615 & 10 & 627 & 9 & 5.7 \\
\hline Zazr@8 & 266 & 2342 & 102 & 8.79 & 0.0612 & 1.24 & 0.8764 & 1.95 & 0.1038 & 1.50 & 647 & 26 & 639 & 9 & 637 & 9 & 5.2 \\
\hline Zazr@9 & 40 & 425 & 15 & 10.55 & 0.0658 & 3.31 & 0.8852 & 3.65 & 0.0975 & 1.54 & 800 & 68 & 644 & 18 & 600 & 9 & 5.9 \\
\hline Zazr@10 & 239 & 1785 & 80 & 7.47 & 0.0601 & 1.65 & 0.8683 & 2.23 & 0.1048 & 1.50 & 606 & 35 & 635 & 11 & 643 & 9 & 5.4 \\
\hline Zazr@11 & 142 & 606 & 32 & 4.27 & 0.0599 & 1.70 & 0.8138 & 2.36 & 0.0986 & 1.64 & 599 & 37 & 605 & 11 & 606 & 10 & 5.3 \\
\hline Zazr@12 & 223 & 614 & 41 & 2.75 & 0.0616 & 1.43 & 0.8425 & 2.11 & 0.0993 & 1.55 & 659 & 30 & 621 & 10 & 610 & 9 & 5.4 \\
\hline Zazr@13 & 210 & 466 & 34 & 2.22 & 0.0611 & 2.10 & 0.8167 & 2.58 & 0.0969 & 1.50 & 643 & 45 & 606 & 12 & 596 & 9 & 5.6 \\
\hline Zazr@14 & 146 & 238 & 23 & 1.62 & 0.0611 & 2.42 & 0.8516 & 2.85 & 0.1010 & 1.51 & 644 & 51 & 626 & 13 & 620 & 9 & 5.8 \\
\hline Zazr@15 & 289 & 1285 & 71 & 4.45 & 0.0609 & 1.18 & 0.8742 & 1.94 & 0.1041 & 1.53 & 635 & 25 & 638 & 9 & 639 & 9 & 5.8 \\
\hline Zazr@16 & 300 & 615 & 52 & 2.05 & 0.0614 & 1.19 & 0.8783 & 1.92 & 0.1037 & 1.50 & 654 & 25 & 640 & 9 & 636 & 9 & 5.6 \\
\hline Zazr@17 & 560 & 627 & 78 & 1.12 & 0.0612 & 0.69 & 0.8294 & 1.65 & 0.0984 & 1.50 & 645 & 15 & 613 & 8 & 605 & 9 & 5.9 \\
\hline Zazr@18 & 293 & 930 & 63 & 3.17 & 0.0606 & 0.96 & 0.8685 & 1.78 & 0.1039 & 1.50 & 626 & 21 & 635 & 8 & 637 & 9 & 5.7 \\
\hline Zazr@19 & 268 & 378 & 42 & 1.41 & 0.0610 & 1.11 & 0.8660 & 1.87 & 0.1030 & 1.50 & 639 & 24 & 633 & 9 & 632 & 9 & 6.1 \\
\hline Zazr@20 & 126 & 913 & 43 & 7.23 & 0.0621 & 1.78 & 0.8511 & 2.32 & 0.0994 & 1.50 & 677 & 38 & 625 & 11 & 611 & 9 & 5.5 \\
\hline Zazr@21 & 278 & 686 & 53 & 2.47 & 0.0604 & 0.93 & 0.8657 & 1.77 & 0.1040 & 1.50 & 616 & 20 & 633 & 8 & 638 & 9 & 5.5 \\
\hline Zazr@22 & 261 & 824 & 56 & 3.15 & 0.0605 & 1.25 & 0.8696 & 1.96 & 0.1043 & 1.51 & 620 & 27 & 635 & 9 & 640 & 9 & 6.0 \\
\hline Zazr@23 & 48 & 127 & 9 & 2.63 & 0.0606 & 3.67 & 0.8418 & 3.97 & 0.1007 & 1.51 & 626 & 77 & 620 & 19 & 619 & 9 & 5.6 \\
\hline Zazr@24 & 209 & 277 & 32 & 1.32 & 0.0610 & 1.50 & 0.8582 & 2.18 & 0.1020 & 1.58 & 639 & 32 & 629 & 10 & 626 & 9 & 5.8 \\
\hline Zazr@25 & 387 & 676 & 58 & 1.75 & 0.0604 & 0.98 & 0.7753 & 1.79 & 0.0931 & 1.50 & 617 & 21 & 583 & 8 & 574 & 8 & 5.8 \\
\hline Zazr@26 & 407 & 475 & 59 & 1.17 & 0.0607 & 0.84 & 0.8619 & 1.72 & 0.1030 & 1.50 & 628 & 18 & 631 & 8 & 632 & 9 & 5.3 \\
\hline Zazr@27 & 1024 & 1284 & 148 & 1.25 & 0.0610 & 0.59 & 0.8358 & 1.62 & 0.0994 & 1.51 & 639 & 13 & 617 & 8 & 611 & 9 & 6.4 \\
\hline Zazr@28 & 76 & 165 & 13 & 2.18 & 0.0596 & 1.96 & 0.8461 & 2.47 & 0.1030 & 1.50 & 588 & 42 & 623 & 12 & 632 & 9 & 5.6 \\
\hline Zazr@29 & 406 & 1012 & 76 & 2.49 & 0.0610 & 0.88 & 0.8624 & 1.76 & 0.1025 & 1.52 & 641 & 19 & 631 & 8 & 629 & 9 & 7.0 \\
\hline Zazr@30 & 103 & 229 & 19 & 2.21 & 0.0610 & 1.65 & 0.8784 & 2.23 & 0.1045 & 1.50 & 639 & 35 & 640 & 11 & 641 & 9 & 6.2 \\
\hline Zazr@31 & 520 & 394 & 71 & 0.76 & 0.0611 & 0.74 & 0.8913 & 1.73 & 0.1058 & 1.56 & 643 & 16 & 647 & 8 & 648 & 10 & 5.8 \\
\hline Zazr@32 & 456 & 860 & 78 & 1.89 & 0.0610 & 0.87 & 0.8839 & 1.76 & 0.1050 & 1.53 & 640 & 19 & 643 & 8 & 644 & 9 & 6.1 \\
\hline Zazr@33 & 238 & 1182 & 65 & 4.96 & 0.0607 & 1.10 & 0.8871 & 1.86 & 0.1060 & 1.50 & 629 & 24 & 645 & 9 & 649 & 9 & 5.9 \\
\hline
\end{tabular}
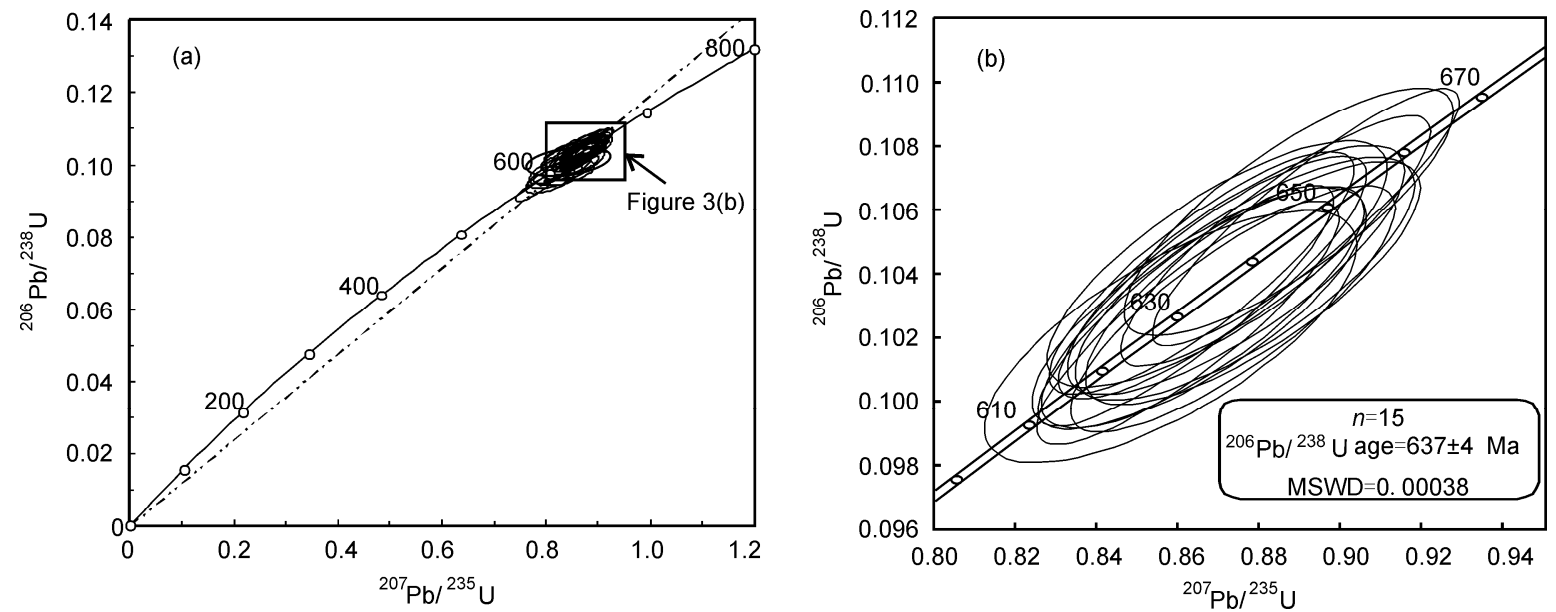

Figure 3 Concordia of zircon $\mathrm{U}-\mathrm{Pb}$ ages. 

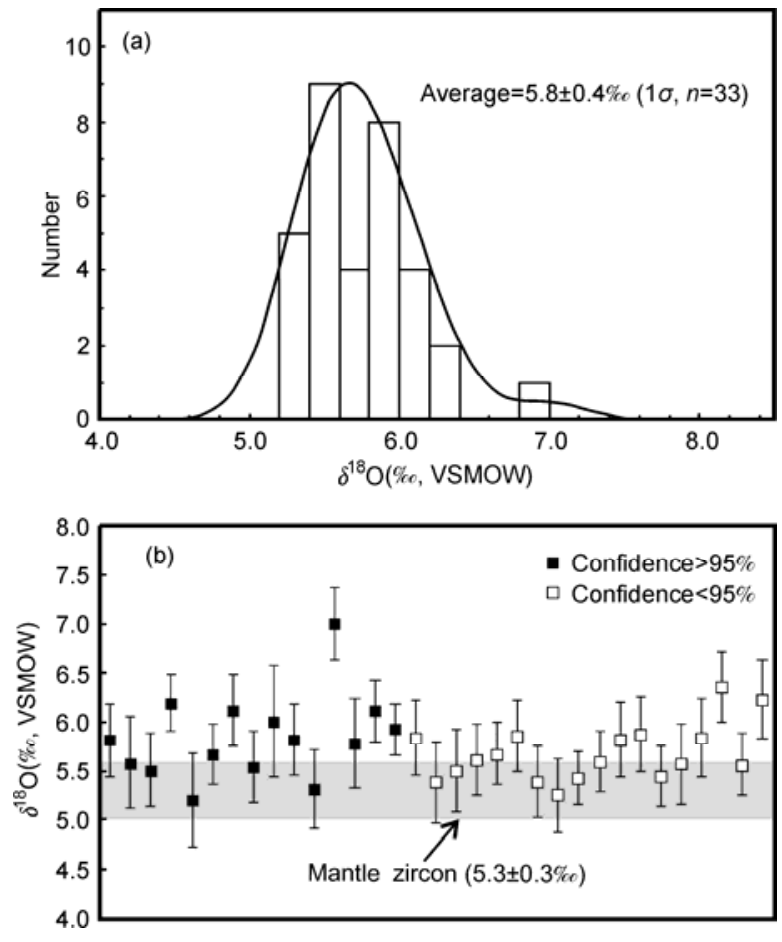

Figure 4 Histogram of $\mathrm{O}$ isotopic compositions (a) and distribution diagram of $\mathrm{O}$ isotopic compositions (b) of zircons. Data source: The $\delta^{18} \mathrm{O}$ value of mantle zircon is from [66].

(1.4-1.6) ratios and high $\mathrm{La} / \mathrm{Sm}(2.3-3.0)$ and $\mathrm{Sm} / \mathrm{Yb}$ (2.1-2.6) ratios. They show weak negative $\mathrm{Nb}-\mathrm{Ta}$ anomalies, positive Ti anomaly and do not have $\mathrm{Zr}$-Hf anomalies in the primitive mantle-normalized trace element patterns (e.g. [16]; our unpublished data), indicating a derivation from an enriched mantle source [69], rather than crustal contamination. Moreover, most zircons of the Zhouan intrusion have $\delta^{18} \mathrm{O}$ values same as the mantle values, indicating that only minor amounts of crustal components may have been incorporated in the mantle source. We therefore consider that the positive $\varepsilon_{\mathrm{Hf}}(t)$ values of the zircons from the Zhouan intrusion are signature of an enriched mantle source.

The rocks from the Zhouan intrusion have nearly constant initial ${ }^{87} \mathrm{Sr} /{ }^{86} \mathrm{Sr}_{(t)}$ ratios $\left(I_{\mathrm{Sr}}\right)(0.7046-0.7055)$ and $\varepsilon_{\mathrm{Nd}}(t)$ values (-4.4-1.1.) They plot in the field near the enriched mantle (EM1) source (Figure 5(b); our unpublished data and Yan et al. [16]). In addition, troctolites from the Duchongshan intrusion $(632 \pm 6 \mathrm{Ma})$ in the Suizao basin have very fractionated LREE/HREE and without $\mathrm{Nb}$, Ta, $\mathrm{Zr}$ and $\mathrm{Hf}$ anomalies, also consistent with a derivation from an enriched mantle source [15]. We therefore conclude that voluminous 640-630 Ma mafic-ultramafic intrusions in the Suizao basin were likely derived from an enriched mantle source.

\subsection{Metasomatism of the mantle source}

Magmas derived from either mantle wedge in an island arc setting or from mantle plume can have prints of an enriched mantle source. In subduction zone, partial melts of pelagic sediments and oceanic slab could be enriched in $\mathrm{Sr}, \mathrm{Nd}$ and Hf [70], the lithospheric mantle that had been metasomatized by the Sr-Nd-Hf-enriched melts may also become enriched [71]. Likewise, plume-derived magmas that had incorporated with recycled ancient pelagic sediments or the lower crust could be also identical to the geochemical features of an enriched mantle source [71].

Slab-derived fluids are generally enriched in LREE and large-ion lithophile elements (LILE), and depleted in high field strength elements (HFSE, e.g. $\mathrm{Nb}, \mathrm{Ta}, \mathrm{Zr}$ and Hf) [72]. Mafic magmas that were generated in an active continental margin setting usually inherited the geochemical characteristics of a metasomatized, enriched mantle source with slabderived fluid [73]. Neoproterozoic mafic-ultramafic intrusions in the Hannan area show arc-like rocks in geochemistry, which was interpreted as a result of the mantle source modified by subducting slab [13]. The rocks from the Zhouan intrusion have low $\mathrm{Nb} / \mathrm{Y}(0.27-0.40), \mathrm{Nb} / \mathrm{Zr}(0.06-0.08)$ ratios and high $\mathrm{Rb} / \mathrm{Y}(0.48-1.64)$ ratios (e.g. [16]; our unpublished data), indicating that the mantle source may have modified by slab-derived fluids/melts (e.g. [9]).

Available whole-rock $\mathrm{Sr}-\mathrm{Nd}$ isotopic compositions and zircon Hf isotopic data indicate that the nature of the mantle sources of Neoproterozoic mafic-ultramafic intrusions and mafic volcanic rocks may have evolved eventually from depletion to enrichment with time (Figure 5(a),(b)). The $\sim 820 \mathrm{Ma}$ Wangjiangshan intrusion has high $\varepsilon_{\mathrm{Nd}}(t)$ values (3.4-3.8), low $I_{\mathrm{Sr}}$ values $(0.7033-0.7037)$ and high zircon $\varepsilon_{\mathrm{Hf}}(t)$ values $(6.0-11.5)$, indicating a depleted mantle source [13]. The 815-800 Ma Beiba intrusion has lower $\varepsilon_{\mathrm{Nd}}(t)$ values (0.2-2.0), higher $I_{\mathrm{Sr}}$ values (0.7038-0.7061) and lower zircon $\varepsilon_{\mathrm{Hf}}(t)$ values (4.5-11.4), features of an enriched mantle source [13]. The 780-735 Ma maficultramafic intrusions have $\varepsilon_{\mathrm{Nd}}(t)$ values $(0.9-3.9)$, lower $I_{\mathrm{Sr}}$ values $(0.7033-0.7039)$ and lower zircon $\varepsilon_{\mathrm{Hf}}(t)$ values (2.9-10.0), also indicating an enriched mantle source [13]. The $\sim 637$ Ma Zhouan intrusion has much low $\varepsilon_{\mathrm{Nd}}(t)$ values $(-4.4-1.1)$, high $I_{\mathrm{Sr}}$ values (0.7046-0.7062) (e.g. [16]; our unpublished data) and low zircon $\varepsilon_{\mathrm{Hf}}(t)$ values (1.3-7.6), indicating a highly enriched mantle source. Likewise, the Neoproterozoic mafic volcanic rocks in the northern margin of the Yangtze Block show similarly compositional variation in the mantle sources. The 950-895 Ma basalts of the Xixiang Formation have whole-rock $\varepsilon_{\mathrm{Nd}}(t)$ values ranging from 8.8 to 4.6 with an arc-like geochemistry, indicating a derivation from a depleted mantle with crustal contamination and formation in a transitional setting from early fore-arc to late back-arc basin [20]. The 840-776 Ma basalts and basaltic andesite from the Bikou Formation have $\varepsilon_{\mathrm{Nd}}(t)$ values from 7.9 to 3.4 , indicating signatures of both depleted and enriched mantle sources [74]. The 778-667 Ma mafic volcanic rocks from the Baishuijiang Formation have 4.6 to $1.1 \varepsilon_{\mathrm{Nd}}(t)$ values [75], similar to $\varepsilon_{\mathrm{Nd}}(t)$ values $(4.6-2.0)$ of the $\sim 755$ Ma mafic volcanic rocks from the Wudang Formation, indicating an enriched mantle source [76]. Mafic volcanic rocks from 
Table 2 Zircon Hf isotopic compositions for the Zhouan intrusion

\begin{tabular}{|c|c|c|c|c|c|c|c|c|}
\hline Spot number & ${ }^{176} \mathrm{Yb} /{ }^{177} \mathrm{Hf}$ & $2 \sigma$ & ${ }^{176} \mathrm{Lu} /{ }^{177} \mathrm{Hf}$ & $2 \sigma$ & ${ }^{176} \mathrm{Hf} /{ }^{177} \mathrm{Hf}$ & $2 \sigma$ & ${ }^{176} \mathrm{Hf} /{ }^{177} \mathrm{Hf}_{(t)}$ & $\varepsilon_{\mathrm{Hf}}(t)$ \\
\hline Zazr@1 & 0.0306 & 0.0003 & 0.0010 & 0.0000 & 0.282527 & 0.000028 & 0.282515 & 5.3 \\
\hline Zazr@2 & 0.0351 & 0.0003 & 0.0012 & 0.0000 & 0.282480 & 0.000022 & 0.282466 & 3.1 \\
\hline Zazr@3 & 0.0200 & 0.0002 & 0.0006 & 0.0000 & 0.282484 & 0.000027 & 0.282477 & 2.8 \\
\hline Zazr@4 & 0.0415 & 0.0004 & 0.0013 & 0.0000 & 0.282559 & 0.000037 & 0.282544 & 5.9 \\
\hline Zazr@5 & 0.0418 & 0.0008 & 0.0014 & 0.0000 & 0.282571 & 0.000028 & 0.282555 & 6.0 \\
\hline Zazr@6 & 0.0325 & 0.0004 & 0.0009 & 0.0000 & 0.282475 & 0.000033 & 0.282465 & 2.1 \\
\hline Zazr@7 & 0.0538 & 0.0006 & 0.0017 & 0.0000 & 0.282507 & 0.000035 & 0.282486 & 3.7 \\
\hline Zazr@8 & 0.0527 & 0.0007 & 0.0016 & 0.0000 & 0.282570 & 0.000030 & 0.282551 & 6.2 \\
\hline Zazr@9 & 0.0243 & 0.0002 & 0.0008 & 0.0000 & 0.282473 & 0.000023 & 0.282463 & 2.3 \\
\hline Zazr@10 & 0.0651 & 0.0025 & 0.0020 & 0.0001 & 0.282549 & 0.000031 & 0.282525 & 5.4 \\
\hline Zazr@11 & 0.0337 & 0.0005 & 0.0011 & 0.0000 & 0.282500 & 0.000021 & 0.282488 & 3.3 \\
\hline Zazr@12 & 0.0346 & 0.0001 & 0.0011 & 0.0000 & 0.282496 & 0.000024 & 0.282483 & 3.2 \\
\hline Zazr@13 & 0.0737 & 0.0017 & 0.0023 & 0.0001 & 0.282620 & 0.000028 & 0.282594 & 6.9 \\
\hline Zazr@14 & 0.0288 & 0.0003 & 0.0009 & 0.0000 & 0.282484 & 0.000028 & 0.282474 & 3.1 \\
\hline Zazr@15 & 0.0261 & 0.0004 & 0.0008 & 0.0000 & 0.282536 & 0.000029 & 0.282526 & 5.4 \\
\hline Zazr@16 & 0.0529 & 0.0013 & 0.0016 & 0.0000 & 0.282608 & 0.000029 & 0.282589 & 7.6 \\
\hline Zazr@17 & 0.0149 & 0.0005 & 0.0003 & 0.0000 & 0.282471 & 0.000027 & 0.282467 & 2.6 \\
\hline Zazr@18 & 0.0213 & 0.0000 & 0.0006 & 0.0000 & 0.282505 & 0.000020 & 0.282498 & 4.4 \\
\hline Zazr@19 & 0.0153 & 0.0001 & 0.0005 & 0.0000 & 0.282465 & 0.000025 & 0.282460 & 2.9 \\
\hline Zazr@20 & 0.0271 & 0.0007 & 0.0009 & 0.0000 & 0.282491 & 0.000029 & 0.282481 & 3.2 \\
\hline Zazr@21 & 0.0313 & 0.0001 & 0.0009 & 0.0000 & 0.282421 & 0.000022 & 0.282410 & 1.3 \\
\hline Zazr@22 & 0.0242 & 0.0002 & 0.0007 & 0.0000 & 0.282457 & 0.000023 & 0.282448 & 2.7 \\
\hline Zazr@23 & 0.0137 & 0.0002 & 0.0004 & 0.0000 & 0.282488 & 0.000022 & 0.282483 & 3.4 \\
\hline Zazr@24 & 0.0178 & 0.0001 & 0.0005 & 0.0000 & 0.282454 & 0.000025 & 0.282448 & 2.4 \\
\hline Zazr@25 & 0.0201 & 0.0001 & 0.0006 & 0.0000 & 0.282473 & 0.000025 & 0.282466 & 1.8 \\
\hline Zazr@26 & 0.0223 & 0.0003 & 0.0007 & 0.0000 & 0.282454 & 0.000021 & 0.282446 & 2.4 \\
\hline Zazr@27 & 0.0400 & 0.0005 & 0.0012 & 0.0000 & 0.282596 & 0.000046 & 0.282583 & 6.8 \\
\hline Zazr@28 & 0.0184 & 0.0001 & 0.0006 & 0.0000 & 0.282554 & 0.000028 & 0.282547 & 6.0 \\
\hline Zazr@29 & 0.0070 & 0.0001 & 0.0002 & 0.0000 & 0.282484 & 0.000020 & 0.282482 & 3.6 \\
\hline Zazr@30 & 0.0081 & 0.0002 & 0.0003 & 0.0000 & 0.282453 & 0.000019 & 0.282450 & 2.8 \\
\hline Zazr@31 & 0.0200 & 0.0001 & 0.0006 & 0.0000 & 0.282500 & 0.000023 & 0.282492 & 4.4 \\
\hline Zazr@32 & 0.0279 & 0.0001 & 0.0008 & 0.0000 & 0.282501 & 0.000020 & 0.282492 & 4.3 \\
\hline Zazr@33 & 0.0311 & 0.0008 & 0.0009 & 0.0000 & 0.282502 & 0.000021 & 0.282490 & 4.4 \\
\hline
\end{tabular}
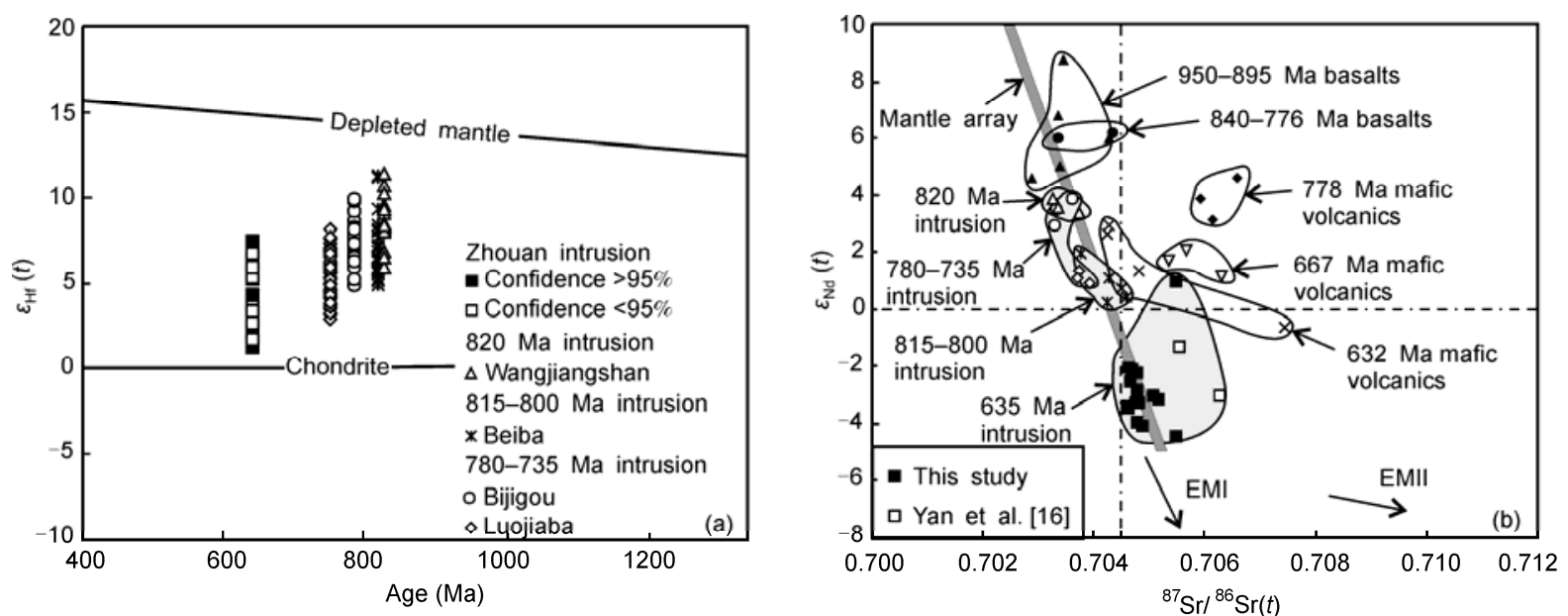

Figure 5 Plots of zircon $\varepsilon_{\mathrm{Hf}}(t)$ values versus U-Pb ages (a) and whole-rock Sr-Nd isotopic compositions (b) of Neoproterozoic mafic-ultramafic intrusions and mafic volcanic rocks. Data source: Zircon Hf isotopic compositions and whole-rock Sr-Nd isotopic compositions of the 820 Ma Wangjiangshan intrusion, 815-800 Ma Beiba intrusion, 780-735 Ma Bijigou and Luojiaba intrusions are from [13]; Sr-Nd isotopic compositions of basalts of the 950-895 Ma Xixiang Formation are from [20]; those of the 840-776 Ma Bikou Formation are from [74]; those of the 778-667 Ma Baishuijiang Formation are from [75]; those of the 632 Ma Yaolinghe Formation are from [77,78]. 
the Yaolinghe Formation have $\varepsilon_{\mathrm{Nd}}(t)(t=632 \mathrm{Ma})$ values ranging from 3.0 to $-0.6[77,78]$, indicating a highly enriched mantle source. Therefore, we suppose that the mantle source of Neoproterozoic mafic-ultramafic intrusions in the northern margin of the Yangtze Block eventually became enriched from $\sim 820 \mathrm{Ma}$ to $\sim 630 \mathrm{Ma}$. The trigger for such transformation is likely to be the metasomatism of the lithospheric mantle with slab-derived fluids/melts [13].

\subsection{Timing of final breakup of the Rodinia supercon- tinent in the northern margin of the Yangtze Block}

Zhao et al. [27] proposed that the Nanhua basin in the southeastern margin of the Yangtze Block was a back-arc basin formed by a long-term subduction of Hannan-Panxi Andean-type continental marginal arc beneath the western and northern margins of the Yangtze Block. The subduction is supposed to have started at $<950 \mathrm{Ma}$ and lasted until $\sim 735$ Ma [9,13,37]. The Zhouan intrusion and other mafic-ultramafic intrusions in the Suizao Basin and the coeval Yaolinghe Formation are considered to have formed in a continental extension setting [45-47], indicating the continental breakup event at $\sim 635 \mathrm{Ma}$. It is therefore suggested that the transformation from subduction to extension in the northern margin of the Yangtze Block may have happened sometime between $<735 \mathrm{Ma}$ and $\sim 635 \mathrm{Ma}$. However, it remains uncertain the exact time of the subduction cease in this period as there was no record of magmatism related to the subduction events in the northern margin of the Yangtze Block.

Intracontinental rifting in the Yangtze Block at Neoproterozoic is proposed to be concurrent with the Nantuo glaciation, the last glaciation at Neoproterozoic [79] based on available age data of the late Neoproterozoic-Sinian Nanhua System and Sinian tillite in the southeastern margin of the Yangtze Block and a comparison of strata between the Nanhua and Kangdian basins. The interlayers of volcanic ash in dolomite at the bottom of the Doushantuo Formation that is underlain by the Nantuo Formation was dated to be $635.2 \pm 0.6 \mathrm{Ma}[80]$, which referred to the end of the Nantuo glaciation $[80,81]$ and is identical to the age of the global Morinoan glaciation and the mafic-ultramafic intrusions and volcanic rocks in the Suizao basin. Therefore, the volcanic ash layers in the Doushantuo Formation may have been generated by $\sim 635 \mathrm{Ma}$ intracontinental rifting of the Yangtze Block. Hoffman [82] suggested that degassing of volcanism resulted in rapid increase of amounts of $\mathrm{CO}_{2}$ in atmosphere, triggering an abrupt change from Snowball to extreme greenhouse on earth. We therefore assume that the Nantuo glaciation may be ended due to $\sim 635 \mathrm{Ma}$, voluminous magmatism in the Suizao basin.

Paleomagnetic data used for the reconstruction of the Rodinian supercontinent show that an $40^{\circ}$ clockwise rotation of the South and West Australian cratons relative to the North Australian craton around a vertical axis in Central changed the trace of the Australian apparent polar wander path (APWP), indicating that the breakup of major continental blocks of the Rodinia supercontinent occurred at $\sim 650 \mathrm{Ma}$ [83]. The 650-630 Ma magmatism are also reported in many places, such as those 650-630 Ma mafic dykes in the northern margin of the Tarim Block [84] and those 650-630 Ma alkaline complexes in the southern margin of the Siberian craton [85]. These intrusions may characterize the last magmatism related to the breakup of the Rodinian supercontinent $[86,87]$. Therefore, we propose that the $\sim 635$ Ma mafic-ultramafic intrusions and coeval bimodal volcanic lavas in the Suizao basin recorded the last magmatism related to the breakup of the Rodinian supercontinent in the northern margin of the Yangtze Block.

\section{Conclusions}

The Zhouan ultramafic intrusion in the Suizao basin is dated at $637 \pm 4 \mathrm{Ma}$ and was derived from an enriched mantle source, which was evolved from the lithospheric mantle metasomatized with slab-derived fluids/melts. A number of $\sim 635$ Ma mafic-ultramafic intrusions in the Suizao basin and the coeval bimodal volcanics of the Yaolinghe Formation indicate a continental rifting setting. They may represent the last magmatism related to the breakup of the Rodinian supercontinent at Neoproterozoic in the northern margin of the Yangtze Block.

This work was supported by the National Natural Science Foundation of China (40972060 and 41073026) and the Hundred Talents Program of the Chinese Academy of Sciences. We thank Zhao Taiping at Guangzhou Institute of Geochemistry for guidance and assistance during the field work. Wang Guomin, Wang Jianming, Li Shengli, Zhang Tieli and Zhang Xing from No.1 Geologic Exploration Team, Henan Bureau of Geology, Ore Exploration and Development are thanked for helping the collection of drill core samples. Li Qiuli and Liu Yu at Ion Microprobe Laboratory and Yang Jinhui, Yang Yueheng and Chen Jingyuan at MC-ICPMS Laboratory in the Institute of Geology and Geophysics, CAS are also thanked for great assistance in data analyses.

1 Zheng Y F. Position of South China in configuration of Neoproterozoic supercontinent. Chin Sci Bull, 2004, 49: 751-753

2 Li Z X, Zhang L H, Powell C M. South China in Rodinia: Part of the missing link between Australia-East Antarctica and Laurentia? Geology, 1995, 23: 407-410

3 Yu J H, O'Reilly S Y, Wang L J, et al. Where was South China in the Rodinia supercontinent?: Evidence from U-Pb geochronology and $\mathrm{Hf}$ isotope of detrital zircon. Precambrian Res, 2008, 164: 1-15

4 Zhou M F, Kennedy A K, Sun M, et al. Neo-proterozoic arc-related mafic intrusions in the northern margin of South China: Implications for accretion of Rodinia. J Geol, 2002, 110: 611-618

5 Zhou M F, Ma Y X, Yan D P, et al. The Yanbian Terrane (Southern Sichuan Province, SW China): A Neoproterozoic arc assemblage in the western margin of the Yangtze Block. Precambrian Res, 2006, 144: 19-38

6 Li X H, Li Z X, Ge W C, et al. Neoproterozoic granitoids in South China: Crust melting above a mantle plume at ca. 825 Ma? Precambrian Res, 2003, 122: 45-83

7 Li X H, Li Z X, Zhou H W, et al. SHRIMP U-Pb zircon age, geochemistry and $\mathrm{Nd}$ isotope of the Guandaoshan pluton in SW Sichuan: 
Petrogenesis and tectonic significance. Sci China Ser D-Earth Sci, 2003, 46(Suppl): 73-83

8 Li X H, Li W X, Li Z X, et al. 850-790 Ma bimodal volcanic and intrusive rocks in northern Zhejiang, South China: A major episode of continental rift magmatism during the breakup of Rodinia. Lithos, 2008, 102: 341-357

9 Zhao J H, Zhou M F. Geochemistry of Neoproterozoic mafic intrusion in the Panzhihua district (Sichuan Province, SW China): Implications for subduction-related metasomatism in the upper mantle. Precambrian Res, 2007, 152: 27-47

10 Zhao J H, Zhou M F. Neoproterozoic adakitic plutons and arc magmatism along the western margin of the Yangtze Block, South China. J Geol, 2007, 115: 675-689

11 Zhao J H, Zhou M F. Neoproterozoic adakitic plutons in the northern margin of the Yangtze Block, China: Partial melting of a thickened lower crust and implications for secular crustal evolution. Lithos, 2008, 104: 231-248

12 Zhao J H, Zhou M F. Melting of newly formed mafic crust for the formation of Neoproterozoic I-type granite in the Hannan region, South China. J Geol, 2009, 117: 54-70

13 Zhao J H, Zhou M F. Secular evolution of the Neoproterozoic lithospheric mantle underneath the northern margin of the Yangtze Block, South China. Lithos, 2009, 107: 152-168

14 Hong J A, Ma B, Huang Q. The Dafushan mafic-ultramafic complex and genesis of the related rutile ore deposit at Zaoyang, Hubei (in Chinese). Chin J Geol, 2009, 44: 231-244

15 Xue H M, Ma F, Song Y Q. Geochemistry and SHRIMP zircon U-Pb data of Neoproterozoic meta-magmatic rocks in the Suizhou-Zaoyang area, northern margin of the Yangtze Craton, Central China (in Chinese). Acta Petrol Sin, 2011, 27: 1116-1130

16 Yan H Q, Tang Z L, Qian Z Z, et al. Zircon U-Pb age and geological significance of Zhou'an copper-nickel sulfide deposit in Henan province (in Chinese). J Lanzhou Univ (Nat Sci), 2011, 47: 23-32

17 Zhou X M, Zou H B, Yang J D, et al. Sm-Nd ischron age and geological significance of the Fuchuan ophiolite suit in Shexian county, Anhui Province (in Chinese). Chin Sci Bull, 1989, 34: 1243-1245

18 Shen W Z, Zhang B T, Ling H F, et al. Nd, Sr and O isotopic study on spilite-keratophyre in Xiqiu, Zhejiang Province (in Chinese). Acta Geol Sin, 1991, 65: 337-346

19 Li X H, Zhou G Q, Zhao J X. SHRIMP ion microprobe zircon U-Pb age of the NE Jiangxi ophiolite and its tectonic implications (in Chinese). Geochimica, 1994, 23: 125-131

20 Ling W L, Gao S, Ouyang J P, et al. Time and tectonic setting of the Xixiang Group: Constraints from zircon $\mathrm{U}-\mathrm{Pb}$ geochronology and geochemistry. Sci China Ser D-Earth Sci, 2002, 45: 818-831

21 Wang X C, Li X H, Li W X, et al. Ca. 825 Ma komatiitic basalts in South China: First evidence for $>1500^{\circ} \mathrm{C}$ mantle melts by a Rodinian mantle plume. Geology, 2007, 35: 1103-1106

22 Li Z X, Li X H, Kinny P D, et al. The breakup of Rodinia: Did it start with a mantle plume beneath South China? Earth Planet Sci Lett, 1999, 173: 171-181

23 Zheng Y F, Zhang S B, Zhao Z F, et al. Contrasting zircon Hf and O isotopes in the two episodes of Neoproterozoic granitoids in South China: Implications for growth and reworking of continental crust. Lithos, 2007, 96: 127-150

24 Wang X L, Zhou J C, Qiu J S, et al. LA-ICP-MS U-Pb zircon geochronology of the Neoproterozoic igneous rocks from Northern Guangxi, South China: Implications for tectonic evolution. Precambrian Res, 2006, 145: 111-130

25 Wang X L, Zhou J C, Griffin W L, et al. Detrital zircon geochronology of Precambrian basement sequences in the Jiangnan orogen: Dating the assembly of the Yangtze and Cathaysia blocks. Precambrian Res, 2007, 159: 117-131

26 Wang J, Li X H, Duan T Z, et al. Zircon SHRIMP U-Pb dating for the Cangshuipu volcanic rocks and its implications for the lower boundary age of the Nanhua strata in South China. Chin Sci Bull, 2003, 48: 1663-1669

27 Zhao J H, Zhou M F, Yan D P, et al. Reappraisal of the ages of Neoproterozoic strata in South China: No connection with the Grenvillian orogeny. Geology, 2011, 39: 299-302

28 Zhang Q R, Li X H, Feng L J, et al. A new age constraint on the on- set of the Neoproterozoic glaciations in the Yangtze Platform, South China. J Geol, 2008, 116: 423-429

29 Wang J M, Chen Y J, Li S L, et al. Geology and genesis of the Zhou'an PGE-Cu-Ni deposit, Henan Province (in Chinese). J Mineral Petrol, 2006, 26: 31-37

30 Naldrett A J. Secular variation of magmatic sulfide deposits and their source magmas. Econ Geol, 2010, 105: 669-688

31 Chen J F, Foland K A, Xing F M, et al. Magmatism along the southeastern margin of Yangtze block: Precambrian collision of the Yangtze and Cathaysia block of China. Geology, 1991, 19: 815-818

32 Qiu Y M, Gao S, McNaughton N J, et al. First evidence of $3.2 \mathrm{Ga}$ continental crust in the Yangtze craton of South China and its implications for Archean crustal evolution and Phanerozoic tectonics. Geology, 2000, 28: 11-14

33 Gao S, Ling W L, Qiu Y M, et al. Contrasting geochemical and $\mathrm{Sm}-\mathrm{Nd}$ isotopic compositions of Archean metasediments from the Kongling high-grade terrain of the Yangtze craton: Evidence for cratonic evolution and redistribution of REE during crustal anatexis. Geochim Cosmochim Acta, 1999, 63: 2071-2088

34 Jiao W F, Wu Y B, Peng M, et al. The oldest basement rock in the Yangtze Craton revealed by zircon $\mathrm{U}-\mathrm{Pb}$ age and $\mathrm{Hf}$ isotope composition. Sci China Ser D-Earth Sci, 2009, 52: 1393-1399

35 Greentree M R, Li Z X, Li X H, et al. Late Mesoproterozoic to earliest Neoproterozoic basin record of the Sibao orogenesis in western South China and relationship to the assembly of Rodinia. Precambrian Res, 2006, 151: 79-100

36 Zheng J P, Griffin W L, O'Reilly S Y, et al. Widespread Archean basement beneath the Yangtze craton. Geology, 2006, 34: 417-420

37 Zhou M F, Yan D P, Kennedy A K, et al. SHRIMP U-Pb zircon geochronological and geochemical evidence for Neoproterozoic arcmagmatism along the western margin of the Yangtze Block, South China. Earth Planet Sci Lett, 2002, 196: 51-67

38 Zhou M F, Yan D P, Wang C L, et al. Subduction-related origin of the 750 Ma Xuelongbao adakitic complex (Sichuan Province, China): Implications for the tectonic setting of the giant Neoproterozoic magmatic event in South China. Earth Planet Sci Lett, 2006, 248: 286-300

39 Yan D P, Zhou M F, Song H L, et al. Origin and tectonic significance of a Mesozoic multi-layer over-thrust within the Yangtze Block (South China). Tectonophysics, 2003, 361: 239-254

40 Zhou M F, Zhao T P, Malpas J, et al. Crustal-contamination komatiitic basalts in Southern China: Products of a Proterozoic mantle plume beneath the Yangtze Block. Precambrian Res, 2000, 103: 175-189

41 Zhao J H, Zhou M F, Yan D P, et al. Zircon Lu-Hf isotope constrains on Neoproterozoic subduction-related crustal growth along the western margin of the Yangtze Block, South China. Precambrian Res, 2008, 163: 189-209

$42 \mathrm{Wu} \mathrm{Y} \mathrm{B,} \mathrm{Gao} \mathrm{S,} \mathrm{Zhang} \mathrm{H} \mathrm{F,} \mathrm{et} \mathrm{al.} \mathrm{Geochemistry} \mathrm{and} \mathrm{zircon} \mathrm{U-Pb}$ geochronology of Paleoproterozoic arc related granitoid in the northwestern Yangtze Block and its geological implication. Precambrian Res, 2012, 200-203: 26-37

43 Gao S, Zhang B R. The discovery of Archean TTG gneisses in the northern Yangtze platform and their implications (in Chinese). Earth Sci-J Chin Univ Geol, 1990, 15: 675-679

44 Ling W L, Gao S, Zhang B R, et al. Neoproterozoic tectonic evolution of the northwestern Yangtze craton, South China: Implications for amalgamation and break-up of the Rodinia Supercontinent. Precambrian Res, 2003, 122: 111-140

45 Xia L Q, Xia Z C, Li X M, et al. Petrogenesis of the Yaolinghe Group, Yunxi Group, Wudangshan Group volcanic rocks and basic dyke swarms from eastern part of the South Qinling Mountains (in Chinese). Northwest Geol, 2008, 41: 1-29

46 Ling W L, Ren B F, Duan R C, et al. Timing of Wudangshan, Yaolinghe volcanic sequences mafic sills in South Qinling U-Pb zircon geochronology and tectonic implication. Chin Sci Bull, 2007, 53: 2192-2199

47 Zhang C L, Zhou D W, Jin H L, et al. Study on the Sr, Nd, Pb and O isotopes of basic dyke swarms in the Wudang block and basic volcanics of the Yaolinghe Group. Chin J Chem, 2001, 20: 193-200

48 Zhang Z Q, Zhang G W, Fu G M, et al. Age of metamorphic strata in Qinling Mountains and its implications (in Chinese). Sci China Ser D-Earth Sci, 1996, 26: 216-222 
49 Zhou D W, Zhang C L, Liu L, et al. Sm-Nd dating of basic dykes from Wudang Block and a discussion of related questions (in Chinese). Acta Geosci Sin, 1998, 19: 25-30

50 Cai Z Y, Xiong X L, Luo H, et al. Forming age of the volcanic rocks of the Yaolinghe Group from Wudang Block, Southern Qinling Mountain: Constrains from grain-zircon U-Pb dating (in Chinese). Acta Geol Sin, 2007, 81: 620-625

51 Li X H, Liu Y, Li Q L, et al. Precise determination of Phanerozoic zircon $\mathrm{Pb} / \mathrm{Pb}$ age by multicollector SIMS without external standardization. Geochem Geophys Geosys, 2009, 10: Q04010, doi: 10.1029/ 2009GC002400

52 Li X H, Li W X, Wang X C, et al. Role of mantle-derived magma in genesis of early Yanshanian granites in the Nanling Range, South China: In situ zircon Hf-O isotopic constraints. Sci China Ser D-Earth Sci, 2009, 52: 1262-1278

$53 \mathrm{Li} \mathrm{X} \mathrm{H,} \mathrm{Li} \mathrm{W} \mathrm{X,} \mathrm{Li} \mathrm{Q} \mathrm{L,} \mathrm{et} \mathrm{al.} \mathrm{Petrogenesis} \mathrm{and} \mathrm{tectonic} \mathrm{significance}$ of the $\sim 850 \mathrm{Ma}$ Gangbian alkaline complex in South China: Evidence from in situ zircon $\mathrm{U}-\mathrm{Pb}$ dating, Hf-O isotopes and whole-rock geochemistry. Lithos, 2010, 114: 1-15

$54 \mathrm{Li} \mathrm{X} \mathrm{H,} \mathrm{Li} \mathrm{W} \mathrm{X,} \mathrm{Wang} \mathrm{X} \mathrm{C,} \mathrm{et} \mathrm{al.} \mathrm{Role} \mathrm{of} \mathrm{mantle-derived} \mathrm{magma} \mathrm{in}$ genesis of early Yanshanian granites in the Nanling range, South China: In situ zircon Hf-O isotopic constraints. Sci China Ser D-Earth Sci, 2009, 52: 1262-1278

55 Li X H, Long W G, Li Q L, et al. Penglai zircon megacryst: A potential new working reference for microbeam analysis of Hf-O isotopes and U-Pb age. Geostand Geoanal Res, 2010, 34: 117-134

56 Sláma J, Košler J, Condon D J, et al. Plésovice zircon - A new natural reference material for $\mathrm{U}-\mathrm{Pb}$ and $\mathrm{Hf}$ isotopic microanalysis. Chem Geol, 2008, 249: 1-35

57 Li Q L, Li X H, Liu Y, et al. Precise $\mathrm{U}-\mathrm{Pb}$ and $\mathrm{Pb}-\mathrm{Pb}$ dating of Phanerozoic baddeleyite by SIMS with oxygen flooding technique. J Anal Atom Spectrom, 2010, 25: 1107-1113

58 Widenbeck M, Alle P, Corfu F, et al. Three natural zircon standards for U-Th-Pb, Lu-Hf, trace-element and REE analyses. Geostand Newsl, 1995, 19: 1-23

59 Wu F Y, Yang Y H, Xie L W, et al. Hf isotope compositions of the standard zircon and baddeleyites used in U-Pb geochronology. Chem Geol, 2006, 234: 105-126

60 Machado N, Simonetti A. U-Pb dating and $\mathrm{Hf}$ isotope composition of zircons by laser ablation-MC-ICP-MS. In: Sylvester P, ed. LaserAblation-ICPMS in the Earth Sciences: Principles and Applications. Newfoundland: Mineral Assoc Can, 2001. 121-146

61 Chu N C, Taylor R N, Chavagnac G, et al. Hf isotope ratio analysis using multi-collector inductively coupled plasma mass spectrometry: An evaluation of isobaric interference correction. J Anal Atom Spectrom, 2002, 17: 1567-1574

62 Söderlund U, Patchett P J, Vervoort J D, et al. The ${ }^{176} \mathrm{Lu}$ decay constant determined by Lu-Hf and $\mathrm{U}-\mathrm{Pb}$ isotope systematics of Precambrian mafic intrusions. Earth Planet Sci Lett, 2004, 219: 311324

63 Blichert-Toft J, Albarède F. Hafnium isotope in Jack Hills zircons and the formation of the Hadean crust. Earth Planet Sci Lett, 2008, 265: 686-702

64 Griffin W L, Wang X, Jackson S E, et al. Zircon chemistry and magma mixing, SE China: In-situ analysis of Hf isotope Tonglu and Pingtan igneous complexes. Lithos, 2002, 61: 237-269

65 Hoskin P W O, Schaltegger U. The composition of zircon and igneous and metamorphic petrogenesis. Rev Mineral Geochem, 2003, 53: 27-62

66 Valley J W, Kinny P D, Schulze D J, et al. Zircon megacrysts from kimberlite: Oxygen isotope variability among mantle melts. Contrib Mineral Petrol, 1998, 133: 1-11

67 Patchett P J, Kouvo O, Hedge C E, et al. Evolution of continental crust and mantle heterogeneity: Evidence from Hf isotopes. Contrib Mineral Petrol, 1981, 78: 279-297
68 Zheng Y F, Zhao Z F, Wu Y B, et al. Zircon U-Pb age, Hf and O isotope constrains on protolith origin of ultrahigh-pressure eclogite and gneiss in the Dabie orogen. Chem Geol, 2006, 231: 135-158

69 Sun S, McDonough W F. Chemical and isotopic systematics of oceanic basalts: Implications for mantle composition and processes. In: Saunders A D, Norry M J, eds. Magmatism in the Ocean Basins. London: Geologic Society, 1989. 313-345

70 Plank T, Langumuir $\mathrm{C} \mathrm{H}$. The chemical composition of subducting sediment and its consequences for the crust and mantle. Chem Geol, 1998, 145: 325-394

71 Viccaro M, Nicotra E, Millar I L, et al. The magma source at Mount Etna Volcano: Perspectives from the Hf isotope composition of historic and recent lavas. Chem Geol, 2011, 281: 343-351

72 Gill J B. Orogenic Andesites and Plate Tectonics. New York: Springer, 1981

73 Münker C. The isotope and trace element budget of the Cambrian Devil River arc system, New Zealand: Identification of four source components. J Petrol, 2000, 41: 759-788

74 Yan Q R, Andrew D H, Wang Z Q, et al. Geochemistry and tectonic setting of the Bikou volcanic terrane on the northern margin of the Yangtze plate (in Chinese). Acta Petrol Mineral, 2004, 23: 1-11

75 Wang T, Wang Z Q, Yan Q R, et al. The formation age and geochemical characteristics of the meta-volcanic rock blocks of the Baishuijiang Group in South Qinling (in Chinese). Acta Petrol Sin, 2011, 27: 645-656

76 Ling W L, Cheng J P, Wang X H, et al. Geochemical features of the Neoproterozoic igneous rocks from the Wudang region and their implications for the reconstruction of the Jinning tectonic evolution along the south Qinling orogenic belt (in Chinese). Acta Petrol Sin, 2002, 18: 25-36

77 Huang X, Wu L R. Nd-Sr isotopes of granitoids from Shaanxi Province and their significance for tectonic evolution (in Chinese). Acta Petrol Sin, 1990, 2: 1-11

78 Zhang Z Q, Zhang G W, Tang S H. Isotopic Geochronology of Metamorphic Strata in South Qinling (in Chinese). Beijing: Geological Publishing House, 2002

79 Wang J, Li Z X. History of Neoproterozoic rift basins in South China: Implications for Rodinia break-up. Precambrian Res, 2003, 122: 141158

80 Condon $\mathrm{D}$, Zhu M Y, Bowring S A, et al. U-Pb ages from the Neoproterozoic Doushantuo Formation, China. Science, 2005, 308: 95-98

81 Hoffmann K H, Condon D J, Bowring S A, et al. U-Pb zircon date from the Neoproterozoic Ghaub Formation, Namibia: Constraints on Marinoan glaciation. Geology, 2004, 32: 817-820

82 Hoffman P F, Kaufman A J, Halverson G P, et al. A Neoproterozoic snowball earth. Science, 1998, 281: 1342-1346

83 Li Z X, Evans D A D. Late Neoproterozoic $40^{\circ}$ interpolate rotation within Australia allows for a tighter-fitting and longer-lasting Rodinia. Geology, 2011, 39: 39-42

84 Zhu W B, Zhang Z Y, Shu L S, et al. SHRIMP U-Pb zircon geochronology of Neoproterozoic Korla mafic dykes in the northern Tarim Block, NW China: Implications for the long-lasting breakup process of Rodinia. J Geol Soc Lond, 2008, 165: 887-890

85 Yarmolyuk V V, Kovalenko V I, Salnikova E B, et al. Late Riphean rifting and breakup of laurasia: Data in geochronological studies of ultramafic alkaline complexes in the southern framing of the Siberian craton. Dokl Earth Sci, 2005, 404: 1031-1036

86 Gladkochub D P, Pisarevsky S A, Donskaya T V, et al. Proterozoic mafic magmatism in Siberian craton: An overview and implications for paleocontinental reconstruction. Precambrian Res, 2010, 183: 660 668

87 Zhu W B, Zheng B H, Shu L S, et al. Geochemistry and SHRIMP $\mathrm{U}-\mathrm{Pb}$ zircon geochronology of the Korla mafic dykes: Constraints on the Neoproterozoic continental breakup in the Tarim Block, northwest China. J Asian Earth Sci, 2011, 42: 791-804

Open Access This article is distributed under the terms of the Creative Commons Attribution License which permits any use, distribution, and reproduction in any medium, provided the original author(s) and source are credited. 